\title{
ТЕХНОЛОГІЯ АНАЛІЗУ КОНФЛІКТУ ПРОЗОВОГО ТВОРУ
}

У статті запропоновано базово-концептуальне бачення конфлікту художнього твору та представлено оригінальну технологію аналізу конфлікту епічно-прозового твору, зокрема роману. Цю технологію апробовано на матеріалі одного з найскладніших з погляду конфліктності романів В. Винниченка ("Божки”) та зроблено належні висновки щьодо ї̈ результативності.

Ключові слова: конфлікт, технологія, аналіз, роман.

В статье предложено базово-концептуальное видение конфликта художественного произведения, представлена оригинальная технология анализа конфликта эпично-прозаического произведения, в частности романа. Эта технология апробирована на материале одного из наиболее сложных в плане конфликтности романов В. Винниченко (“Божки”), сделань соответствующие выводы о её результативности.

Ключевые слова: конфликт, технология, анализ, роман.

The paper proposed a base-conceptual view of the conflict of art and technology presents an original analysis of the conflict-epic prose works such as the novel. This technology has been tested on the material of one of the most difficult in terms of conflict of novel of V. Vinnychenko "Gods», made conclusions about its effectiveness.

Key words: conflict, technology, analysis, novel.

Проблема конфлікту художнього твору взагалі і твору прозового зокрема вже давно стала в літературознавстві актуальною, але залишилася так до кінця й не вирішеною.

В. Удалов указав на той факт, що “недостатнім $є$ загальне визначення категорії “конфлікт”, недостатньо усвідомлена спільна “основа” конфлікту й колізіі”, і досі остаточно не висвітлено відмінності конфліктів драматургічних та епічних творів [Удалов 1995: 68], а все це ще “чекає свого висвітлення крізь об'єктивний зв’язок конфлікту, колізії, конфліктності у творі як образній сис- 
темі” [Удалов 1995: 70]. С. Хороб, визнаючи актуальність вирішення проблеми теоретико-прикладного значення конфліктів, найперспективнішим бачив «підхід до неї як до явищза полі функціонального» [Хороб 1999: 27]. За твердженням цього автора, «художня, наукова думка мусять щоразу максимально динамізуватися в новому осмисленні иүієї вузлової ідейно-естетичної категорії, вишукувати і досліджувати ї̈ нові риси, характерні особливості» [Хороб 1999: 27]. I Р. Гром'як твердить: «Замість емпіричного опису та класифікачії численних проявів конфлікту в житті і мистецтві здійснювалися спроби віднайти їх глибинні і фундаментальні основи, виявити іманентні механізми» [Гром'як 2004: 9-10].

Та й у підручниках з теорії літератури (таких авторів, як В. Халізєв [Халізєв 1999], , Н. Тамарченко, В. Тюпа, С. Бройтман [Тамарченко 2004], Е. Фесенко [Фесенко 2008] та ін.) немає одностайності ні в дефініціях понять “ситуація", “колізія”, “конфлікт”, “конфліктність”, ні в підходах до вивчення названих явищ у твоpax епічного та драматургічного плану. Як правило, все розпочинається із “гегелівського" різнотлумачення “тимчасового порушення рівноваги сил” [Тамарченко 2004: 193], і продовжується так само “гегелівською” ідентифікацією або взаємозаміною понять “колізія” і “конфлікт”, що не дає можливості розібратися навіть у базових структурах поєдинків і протистоянь.

Навіть при вивченні конфліктів творів драматургії у концептуальних літературознавчих працях із потужними, хоч і не дефініційно-одностайними, теоретичними викладками (Й. Кисельова [Кисельов 1962], М. Суркіна [Суркін 1965], В. Муромського [Муромський 1966], В. Сахновського-Панкеєва [Сахновський-Панкеєв 1969], В. Нефеда [Нефед 1970], А. Карягіна [Карягін 1971], Ю. Корзова [Корзов 1991], С. Хороба [Хороб 1999], Д. Катишевої [Катишева 2001] та ін.) допускаються різнотлумачення як базових ознак змістоформ та функцій досліджуваних явищ, так і сутності та співвідношень їхніх складових. Ще більше відмінностей у працях про конфлікти епічно-прозових творів, навіть у найпотужніших 
(Д. Іванова [Іванов 1961], Й. Кисельова [Кисельов 1962], А. Погрібного [Погрібний 1981], С. Хороба [Хороб 2000], М. Нореця [Норець 2008]). Лише дослідники конкретних епічно-прозових жанрів окреслюють окремі специфічні ознаки конфліктів у них (Г. Лукач [Лукач 1994], Б. Грифцов [Грифцов 1926], С. Мелетинський [Мелетинський 1964], В. Кожинов [Кожинов 1964], Г. Косіков [Косіков 1994]).

Тобто, проблеми осягнення конфліктів епічно-прозових творів сьогодні все ще лишаються остаточно не вирішеними. А тому в даній статті здійснюється спроба реалізувати таку технологію аналізу конфлікту епічно-прозового твору (зокрема, роману), в процесі виконання якої не тільки охоплюються всі без винятку складові конфлікту, а й усі основні співвідношення між ними. Вихідну концепцію в основному розглянуто автором в праці “Основные этапы и достижения современного литературоведения в решении концептуальных проблем конфликтов романов" (Москва, 2013). У іiі основу покладено погляди на конфлікт твору художньої літератури як на безпосередньо такий процес, котрий виникає, формується й розгортається з тих першопочатків, які більшість дослідників не те, що ігнорують, а здебільшого просто не помічають - із сумнівів та суперечностей, котрі не лише зумовлюють усвідомлення сутності й характеру конфліктуючих протилежностей, а й складають разом повноцінні й функціональні конфліктні ситуації. А далі, взявши за основу найпереконливішу, на наш погляд, схему структури конфлікту, запропоновану професором А. Козловим [Козлов 1997: 84] і доповнивши іiі поняттям про той наслідок, про який, як правило, говориться у творі епічно-романного типу після розв'язки і який може бути ще й своєрідною “відповіддю” на згаданий уже первісний сумнів і на породжену ним суперечність і на вищий сенс конфліктування, ми сформулювали таке базовоконцептуальне визначення: конфлікт твору художньої літератури (будь-якого і перш за все широко "розгорнутого" у часопросторі і в суспільстві, наприклад, роману) - це система таких функціонально-визначальних станів психіки персонажів, котрі готують їх до 
поєдинку і таких поодиноких зіткнень (колізій) між протилежними думками, словами, діями, вчинками, точками зору, позиціями, принципами, методами, світоглядами носіїв протилежностей, кожне $з$ яких має змістоформу, ознаки, функції та сутність, а також прояву після конфліктних наслідків. Оскільки в центрі уваги завжди стоять власне конфліктні зіткнення (колізіi), нагадаємо: перше зіткнення, остаточно окреслюючи сутність і основні риси характерів конфліктантів, служить початком (“зав’язкою”) конфлікту (крім того, воно збуджує психіку реципієнта, захоплює його уяву й породжує перші переживання); друге або й кілька наступних зіткнень (колізій) відзначаються перш за все тим, що кожне з них посвоєму поступово напружує й загострює протидію конфліктантів (а ще заряджає реципієнта гострою необхідністю того пізнання (за висловом Платона, “знання»), від якого він відмовитися вже не може); найгостріше зіткнення (“кульмінація” або “апогей”) не лише виявляє максимальні потенції конфліктантів і попередньо вказує на реальні можливості остаточної перемоги однієї з протилежностей або одного з конфліктантів (а ще й визначає ставлення реципієнта до кожного з них); завершальне зіткнення (“розв’язка”) не тільки є виявом остаточної перемоги одного з конфліктантів, а ще може вказувати й на можливість конфліктування або гармонізації стосунків персонажів на наступних етапах їхнього співіснування, чим продовжує утримувати увагу реципієнта, i, звичайно, породжує в ньому глибокі роздуми і над загальним станом стосунків загалом (постконфлікта ситуація).

Крім того, цілком приймаючи думки тих теоретиків, які сам процес конфліктування і структуру конфлікту (а дехто й типи конфліктів) вважають по-своєму універсальними для всіх родів, видів і жанрів літератури (П. Волинський [Волинський 1967: 114, 115, 119, 120], I. Масеєв [Масєєв 1958: 163], А. Погрібний [Погрібний 1981: 15, 89, 98], А. Козлов [Козлов 1997: 84] та ін.), все-таки визнаємо, що у творах різних розмірів і родовидових типів немає однакових можливостей подавати всю запропоновану нами схему 
конфліктування як названої системи, а найбільші можливості для цього $є$, звичайно, у романах. Більше того, саме в романах процеси конфліктування можуть бачитися й зображатися фактично на всіх рівнях свідомості й надсвідомості персонажів художнього твору автор справді має всі можливості для показу специфіки навіть передконфліктних ситуацій, усіх особливостей змістоформ, ознак найпредбачуваніших і власне сутнісних функцій кожної з колізій і будь-яких наслідків кожного 3 конфліктів “великих” епічнопрозових творів - аж до детальних описів взаємовпливів складових системи конфліктів романів.

Отже, спираючись на сформульовану концепцію конфлікту (і передусім конфлікту епічно-прозового твору, роману), спробуємо апробувати не так методику, як процесуально-результативну технологію дослідження конфліктних ситуацій (сумнівів, суперечностей, протилежностей), змістоформи, ознак, функцій і сутності кожної окремої колізії й конфлікту та конфліктності в цілому, а також тих наслідків, які стають причинами інших процесів. Сутність цієї технології полягає в тому, що вказані стани, процеси й наслідки всього представленого явища розглядаються поетапно, послідовно й у поступу чи розвитку (якими наділив їх автор - від якостей складових конфліктної ситуації, характеру дієвості кожної окремої складової, тобто від характеру кожної окремої колізії і всього конфлікту та дієвості післяконфліктних наслідків, які сприяють чи не сприяють утворенню системи поєдинків твору і визначають післяконфліктну долю кожного з персонажів роману - аж до особливостей системи конфліктів автора). У цьому плані особливу увагу привертають конфлікти романів В. Винниченка 1910-1916 pp.

Та передусім апробуємо вказану технологію лише на одному, але чи не найбільш конфліктному, з романів В. Винниченка “Божки" (1913) .

Поставивши в центр цього твору процес внутрішнього конфліктування героя, Вадима Стельмашенка, автор розпочинає розповідь про неоднозначний стан Вадима $з$ опису важких сумнівів, 
від яких герой, за авторським баченням, “корчився” [Винниченко 1928: 6] відчував себе надумано й неприродно “пустельно", бо сумніви знову й знову викликали внутрішні роздуми й бажання самостійно осмислити все, що роздвоювало його свідомість - аж до осягнення тієї ситуації, в яку він потрапив. Ця конфліктна ситуація відіграє роль, так би мовити, загальної. Тільки довготривалі сумніви й суперечливі роздуми героя привели його до осмислення складу тих протилежностей, котрі найбільше, найчастіше і найболючіше тривожили його: перше - природна протиставленість закономірностей розвитку природи взагалі й природи людини зокрема всьому тому, що видавалося йому штучним і надуманим, що протистоїть природі й природності людського. Це свідчить на користь того, що герой роману вже вийшов на вищий, загальнолюдський, масштаб і рівень осягнення таких протилежностей, котрі можна усвідомлювати не на основі революційно-контрреволюційних, щирих і лицемірних, чесних і нечесних гасел та перетворень, ідей та ідеологічних гіпотез, а на основі глибоких філософських положень, законів і закономірностей розвитку матерії, людини й суспільства. Тому-то герой не кидається на захист будь-якої “благої” ідеї чи справи, а намагається розібратися в причинах і мотивах відвертої і прихованої непослідовності та брехливості людей, у сутності та цілеспрямованості їхніх визначальних думок, позицій, дій. I хоча йому не вдалося справді по-філософськи осягнути всі причини “розбрату”, він зрозумів: “возлюбивши” людей загалом, людина може при цьому потрапити в оточення “ближніх”, скалічених життям без любові: “Коли б я не возлюбив людськість, а возлюбив батьків, нічого подібного з ними не було б” [Винниченко 1928: 6]. Але трагізм становища героя полягав у тому, що навіть синівські інстинкти й обов'язки так остаточно й не перемогли Вадим зрозумів, що його боротьба із загальнолюдськими "божками” - це не лише виплески особистісної “енергії справедливости” [Винниченко 1928: 7], а й імпульси тієї боротьби, яка розгортається й навколо нього, поступово набуваючи масового характеру. 
Особистим випробуванням внутрішньої цілісності духу героя стала ситуація, в якій, здавалося б, повністю збайдужілий до лицемірної та поверхової суспільної думки Вадим зустрічає свого брата Ося і його товариша Антошку, адже останній, бойкотуючи героя, зневажливо відвертається від нього. Саме тоді у “байдужого” Вадима раптом “важко ухнуло < ..> серие й кров гаряче кинулась в лище” [Винниченко 1928: 16], а сам він надовго занурився у нові сумніви й суперечності [Винниченко 1928: 16]. Таким був лише початок осягнення героєм протилежностей - він лише наблизився до реальної зав'язки, тобто, до першого суттєвого дієвого зіткнення із самим собою.

Саме тому Вадим, сама присутність якого обтяжувала Ося, “тягнув його”[Винниченко 1928: 17], майже силоміць, до себе на квартиру i, хвилюючись, виправдовувався (більше перед собою) за історію з Наташею, за бойкот, за те, що не зумів довести товаришам-соціалістам, що він “ощасливив” Наташу й таке подібне [Винниченко 1928: 23-26]. I саме тоді, коли йому вже вдається справити на брата позитивне враження, його нестримне бажання нищити “божків” призводить до необхідності закінчити свої “самовиправдання” таким “модернізованим” висновком: “Всякі нещзастя, неудачі для тебе дурниия. Ти вище всього того. <..> ти не реатуєш, бо ти не маєш почувань. <... Це модерно. <..> я от їхав $і$ бачив, як на мойх очах мерли з голоду люди. Я нічого. < ..> От ие сила!" [Винниченко 1928: 28-29]. Та герой не передбачив, що цей висновок перетворить його внутрішній конфлікт на поєдинок із братом: “Слухай, Вадиме! <..> Я - член робітничого товариства "Гартованиі". < ..> Ціль изього товариства - ті самі божки, з яких ти глузуєш: правда, справедливість, добро...” [Винниченко 1928: 31], - категорично заявив Ось. I наостанок у цій суперечці-колізії брат не тільки назвав Вадима “сволоччю”і “падлюкою" [Винниченко 1928: 35], але й пообіцяв зарізати “своїми руками" [Винниченко 1928: 36]. Наслідком цього зіткнення став для Вадима жахливий психічний стан: “В грудях болить. Болить так само, 
як тоді, коли “ті” проголосили мені бойкот, коли я вечорами блукав коло їх хат, годинами простоюючи на городах <... . Для чого ж два роки самоти, мовчання і мовчазного здушування себе я приняв на себе?" [Винниченко 1928: 37-38].

У такий стан герой почав потрапляти і майже після кожного внутрішнього роздуму про “божків” - після безперервних сумнівів та суперечностей і внутрішніх суперечок, які часом переростали в гострі внутрішні колізії, і в такі результативні висновки та самооцінки, котрі доводили його майже до безглуздя [Винниченко 1928: 38].

Наступна внутрішня колізія-суперечка героя вибудовується на протиставленні суспільних регламентацій і особистісних мотивів поведінки, на удаваній “байдужості” до них та до всього людського взагалі: “Я, наприклад, можу взять грошей у добродія Микульського. Я маю повне право на це, я свої, зароблені гроші беру. I не можу! I в тому, щио не можу, щуо зщулююсь весь, як тільки подумаю, щуо звертаюсь до його, - і єсть моя непростима слабість" [Винниченко 1928: 180-181].

Розгортання ж основних подій роману стає лише своєрідним “фоном” для начебто безкінечних колізій-суперечок героя із самим собою: відкидання ним “божків” взагалі й “суспільна частина”, в якій вони глибоко закорінені, безперервно борються, ускладнені хронічними сумнівами й суперечностями, виявляються іноді у формі таких публічних промов, під час яких він і сам то раптом починає “крушити” “божків” на зібранні соціалістів, то раптово визнає: “Не знаю, яке вражіння на них зробили мої слова. Та й не для вражіннь я говорив їм. Тоді, може, так $і$ думав, але тепер знаю, щуо через підлоту свою, для неї говорив! <...> Я всіма силами своєї брехливої душі бажав показати їм, от, мовляв, який я" [Винниченко 1928: 197].

А в результаті саме цієї внутрішньої колізії Вадим потрапив у такий стан, що вже “зовсім не володів собою”, а його свідомість перетворилася на суцільну “лаву хворого гніву” [Винниченко 1928: 199-200]. Так від однієї внутрішньої колізії до іншої конф- 
лікт героя із самим собою (знову ж таки, через безліч сумнівів i суперечностей) став набирати вже по-справжньому кульмінаційної гостроти: “Взагалі, я тепер нічого не знаю й не розумію <.... . Я весь розлізаюсь, як розсохла діжка" [Винниченко 1928: 217].

І невдовзі все це почало переростати не просто в суцільний потік сумнівів і суперечностей, а в стан своєрідної агонії, особливо тоді, коли Вадим закохався в Олесю Микульську, хоча й бачив у ній представницю “панів” і “служницю” “божків” одночасно. А все це разом повільно, але неминуче вело подієвий ряд твору i ряди колізій внутрішнього конфлікту героя до кульмінації і такого незвичайного фіналу, який став не просто завершальним етапом внутрішнього конфліктування, а й новим процесом наповнення тепер уже кожного поруху його думки суцільними сумнівами й суперечностями. Та навіть і тоді (та ще й коли йому дуже знадобилися гроші) Вадим не одразу пристав на пропозицію Тепи принизити в іiі присутності Олесю (“в ту ж хвилину, як виженете Микульську, дам вам п'ятсот рублів” [Винниченко 1928: 326]), а спочатку відповів рішучою відмовою [Винниченко 1928: 325-326]. А коли він все-таки погодився на таку підлість, у його свідомості максимально загострився і поєдинок протилежностей. 3 одного боку, йому хотілося раз і назавжди вирішити всі сумніви й суперечності (“Треба нарешті раз кінець зробить” [Винниченко 1928: 337]), a, з іншого, постала необхідність і можливість “виправдатися» перед братом і соціалістами (“Братуха, хлопчик мій мене за зрадника мав, а тепер похвалить, щуо такий молодецьь, грошей дістав" [Винниченко 1928: 338-339]). Більше того, Вадимові здалося, що гроші, якщо їх використати для підтримки страйку, стануть “чистішими всяких божків” [Винниченко 1928: 338], давши урок захисниці “божків” Олесі.

Та, вигнавши в такий спосіб Олесю, Вадим лише "лежав без pyxy, як ранений” [Винниченко 1928: 349-350] - кульмінація внутрішнього поєдинку із самим собою мала для нього найгірші наслідки, обійшовшись його внутрішньому станові ще дорожче - Ва- 
дим і сам відчув, як він утратив особисте “обличчя”, перетворившись із героя роману на головного персонажа. I хоча все це склало ту саму функціонально-наслідкову ситуацію, в якій формувалися нові сумніви й суперечності та конфлікти, напруга цих нових внутрішніх протиставлень майже зовсім зникла, в них Вадим упізнавав колишні попередні сумніви й суперечності, що породжувало нові стани апатії та депресії. Протилежності “розмивалися», втрачали не лише вагомість, а й елементарні “межі” між правдоюнеправдою, “праведністю” та “гріховністю” Вадимового буття взагалі: “як тоскно мені, Боже, як тоскно й тривожно! Я не бачу самого себе... Піти хіба до Ося, до Антошки, до Ріни й сказать їм: “Годі, я не можу більше!”? < ...> Самолюбство, божок мій, боїться й корчиться в мені. А от піти й прилюдно плюнуть йому в стару погану пику його. Схилити свою голову і сказати... Що сказати? Все одно, щуо хоч. Правду? Яку правду? Чи брехню? Яку брехню?" [Винниченко 1928: 359-360]. Не побачивши виходу із такого стану, Вадим визнає: "Нi, я, таки, здається, хворий, мушу изе признати. Мені б варто кудись виїхати, одійти від изього всього" [Винниченко 1928: 359]. У такому стані Вадим так “плює” на “божків", що все ж не “запльовує” їх остаточно, адже від жодного зі своїх протилежних поглядів він так і не відмовився.

Отже, наскрізний і центральний конфлікт “Божків", формувався й “сплітався” із великої кількості найрізноманітніших особистісних сумнівів і суперечностей, але з реальних психологічних $\mathrm{i}$ психофізіологічних колізій, які фактично склали найоб'ємнішу частину змісту роману, порушили так багато питань (і способів рішення) проблем особистого, громадського та суспільного буття людини й не розв'язав практичного жодного з них остаточно. При цьому головний персонаж постійно відкриває в собі не два, а значно більше "я”, які, дискутуючи між собою, виходять і “за межі" його свідомості, включаються в колізії зовнішнього світу. Майже кожна окрема колізія такого наскрізного й неоднозначного внутрішнього конфлікту (але передусім кульмінаційна та завершальна) 
приводять до безповоротної втрати спочатку основних рис характеру, а потім і тих ознак та характеристик, котрі на початку роману давали читачеві підстави вважати Вадима начебто стійким та оригінальним, здатним постати “над оточенням”.

Цьому основному наскрізному внутрішньому конфліктові головного персонажа виразно підпорядковано два додаткові конфлікти. Перший із них - конфлікт Вадима 3 його молодшим братом Осем, уже із самого початку вмонтовується в основу особистих сумнівів і суперечностей Вадима. Так, герой дивиться та брата i думає: "Через що брат мусить хвилювати, цікавити, тягнути? $<\ldots .>$ Через щзо я через його такі дурниці роблю? Через нього, через нього!” [Винниченко 1928: 15]. I хоча у колізії-зав'язці Ось начебто мав щодо Вадима впевнену й стійку позицію: “Я тобі не “голубчик” $і$ не брат. <...> в тебе нічого святого нема" [Винниченко 1928: 32], а все ж остаточної й повної протилежності їхніх поглядів і позицій брати так і не з'ясували - родинні стосунки не давали братам стати відвертими антагоністами. Та й той факт, що Вадим був справжнім інтелігентом, теж дозволив перевести поодинокі зіткнення в план інтелектуальних дискусій, що особливо чітко проявилося під час публічної кульмінаційної суперечки братів [Винниченко 1928: 201-202]. А коли Ось побачив, якими голодними очима дивився Вадим на "нарізану шинку, ковбасу, сало" [Винниченко: 202], він одразу зрозумів: брат такий “красномовний”, тому що вже кілька днів нічого не їв. Цей факт і вирішив їхню кульмінаційну колізію, а згодом і весь конфлікт між братами: від сорому Вадим, “шарпнувшись, <...> вибіг з кімнати” [Винниченко 1928: 203], але скоро почув, як біг навздогін йому Ось i“винувато, жалко, з болючим лицем мовчки дивився" на нього [Винниченко 1928: 204]. Тільки тут Вадим зрозумів: “Він великодушніший за мене й розумніший” [Винниченко 1928: 206]. I це була не лише "розрядка" кульмінаційної колізії конфлікту, а й реалізація принципової сутності розв’язки: брати одкинули свої “ідейні” протилежності, і помирилися тільки тому, що відчули 
родинний зв'язок одне з одним - він виявився вищим за “гартованство” одного та “імморалізм” іншого. А читаючи момент, як Ось “узяв Вадима за плащ і хмуро-соромливим дитячим голосом бовкнув: “Я тебе люблю, Вадя...” [Винниченко 1928: 340], реципієнт розуміє, що це - один із небагатьох Винниченківських конфліктів, котрі при всій гостроті колізії вирішуються повною гармонізацією конфліктантів. Основна його функція - постулювання автором ідеї, що кращі братні почуття, кращі інстинкти людини завжди стоять і мають стояти вище будь-яких суспільних чи соціальних симпатій, партійних, ідеологічних чи будь-яких інших суспільно регламентованих типів поведінки та приналежностей.

Інший, зовнішній і так само виразно підпорядкований внутрішньому конфліктові Вадима виявився його поєдинок із Тепою, колишньою коханкою. Цей поєдинок ми теж бачимо через призму внутрішнього двобою Стельмашенка. Певна “провокативність" цього конфлікту полягає в тому, що Вадим намагається показати себе i“мморалістом”, котрий прагне ігнорувати всі моральні регламентації (як суспільні, так і загальнолюдські). А Тепа, такого не постулюючи і навіть не усвідомлюючи, $є$ людиною, чи більше істотою, яка дійсно ігнорує всі можливі (і перш за все моральні) регламентації. Для неї по-справжньому, а не на словах, немає ні “божків”, ні богів, ні Бога, ні суспільства, адже це просто “сластолюбива, розпутна, свавільна сука" [Винниченко 1928: 69]. Так і “вималювалася" нова пара конфліктантів: удаваний "іммораліст” і справді аморальна істота. Цей конфлікт має чітко окреслені колізії, високий драматизм, що теж робить його схожим на “сценічний”, але сама наявність його у творі в якості підпорядкованого центральному внутрішньому конфліктові Стельмашенка доводить: між удаваним “імморалістом” і дійсно аморальною людиною - прірва.

Отже, розглянуті в такий спосіб першопланові конфлікти твору постають своєрідною системою конфліктів роману адже вони об'єднані підпорядкованістю внутрішньому конфліктові ге- 
роя й одним конфліктантом, а, крім того, ще й мають спільний функціонально-наслідковий стан його повної розгубленості.

Однак при цьому не залишилися поза авторською увагою й такі конфлікти, які ми сповна правомірно можемо визначити як “присистемні”. Прямо структурно вони не підпорядковуються розглянутій системі, але поєднуються іншим зв'язком - загальною системою конфліктів роману і на інших рівнях ілюструють важливу ідею твору - $є$ такі, передусім суспільні, “божки”, з якими боротися не просто треба, а й необхідно.

Деякі з цих конфліктів “другого” плану виконують функції поєдинків, котрі напружують передусім протистояння сімейних інтересів. Наприклад, це ті ж таки, що у “По-свій!”, щоденні побутові конфлікти між Модестом та Діною Микульськими: Модест прагне зберегти сім'ю за усяку ціну, він - охоронець інтересів їхнього сина і традиційних шлюбних цінностей; Діна, знаючи це, пиячить, зраджує, не піклується про дитину, прагне лише грошей $\mathrm{i}$ мати коханців. Усе їхнє життя - ряд щоденних побутових сутичок, у яких жодна сторона не перемагає, адже порушити “святість" шлюбу Модест нездатний: “Коли б я не вважав за обов’язок женитись на изій тварі, я б півжиття собі й другим урятував" [Винниченко 1928: 160]. Такі конфлікти введені автором для підкреслення ненормальності атмосфери в подібних родинах, адже шлюб там тримається лише на дотошному дотриманні правил поведінки. Майже аналогічним бачиться і поєдинок “третього” плану (про нього згадується лише один раз) між подружжям Піддубних.

У романі, крім названих, наявні ще кілька "присистемних" конфліктів “другого” плану. Одним 3 таких $є$ внутрішньозовнішній конфлікт Юрія Микульського, ускладнений не лише величезною кількістю сумнівів і суперечностей персонажа, але й цілим рядом «похідних» зовнішніх колізій із іншими персонажами. Внутрішній конфлікт Юрія - це поєдинок в ньому “соціалдемократа" [Винниченко 1928: 113] і “дворянина” [Винниченко 1928: 114], одразу ж спричинив не лише внутрішню колізію- 
суперечку, а й гостру колізію з його поміщицькою родиною (родинний “суд”) [Винниченко 1928: 113-119]. При цьому сумніви, суперечності, хитання і постійні внутрішні суперечки з самим собою настільки “роз’їли” нестійку психіку нещасного, що він почав “ховатися” в “обіймах" морфію [Винниченко 1928: 120]. А поява двох наречених (Ріна активно намагалася навернути Юрія до “соціалістичного” способу життя, [Винниченко 1928: 119], а за одруження із поміщицької донькою Галею (жінкою “їхнього кола”), дівчиною з “локонами й синіми очима ляльки” [Винниченко 1928: 162], активно виступала вся родина Микульських), привела Юрія не лише до стану хронічної невпевненості і ряду “зовнішніх” суперечок-сварок, а й до кульмінаційної колізії, у ході якої він запропонував Галі стати його дружиною. Персонаж нібито остаточно розв'язує внутрішній конфлікт, коли говорить сестрі Олесі: “Тепер уже нікуди й ніколи я не піду. Я в а ш” і у відповідь бачить “тихо-щзасливе, просвітлене лице” іiі [Винниченко 1928: 290-291], але сумніви все одно залишаються 3 ним.

Тобто, цей конфлікт, з одного боку, демонструє спробу такої ж внутрішньої боротьби персонажа, як і боротьба Вадима, а, з іншого, неминуче “заспокоює” людину зі слабкою психікою й таким же характером. А тому однією з функцій цього конфлікту стала можливість “озвучити” авторську недовіру до соціалістів дворянського походження, котрі, на його думку, ніколи не зможуть сприйняти світогляд соціалістів.

Отже, в романі “Божки” головним і наскрізним конфліктом зображено внуртішній поєдинок головного персонажа Вадима Стельмашенка, який постає 3 конфліктної ситуації (багатьох сумнівів, суперечностей та протилежностей) і містить чітку систему колізій, яка, до того ж, тісно переплітається із системами колізій підпорядкованих йому конфліктів. При цьому більшість функціонально-наслідкових ситуацій виявилися логічно й тематично пов'язаними одна $з$ одною настільки тісно, що й весь твір загалом справляє враження цілісного й художньо довершеного. 
А це значить, що апробована технологія аналізу конфлікту навіть такого складного твору, як роман "Божки”, дозволяє не лише всебічно й детально вивчити практично віс основні аспекти конфліктів твору, а й зробити ряд таких висновків. По-перше, абсолютно очевидним є визнання правомірності розглянутої структури процесу конфліктування: конфліктної ситуації (сумніви, суперечності, протилежності), власне конфлікту як системи колізій, системи конфліктів твору та функціонально-наслідкової ситуації. По-друге, застосована технологія дозволила з'ясувати різні види зв'язку між усіма складовими конфлікту і між конфліктами взагалі й визначити відповідні типи конфліктів: “системний”, “присистемний”, “першого” плану, “другого” (“третього”) планів, “закритий” та “відкритий”, художньо довершений (“повноцінний”), художньо недовершений (“неповноцінний”) тощо. По-третє, застосування такої технології вивчення конфліктів може бути не менш ефективним при дослідженні конфліктів творів рівзних жанрів, але це вже скоріше наступна проблема спеціального й системного дослідження. По-четверте, на етапі особистісної родинної, групової, соціальнщїй, ідеологічно-групової, національної, суспільної життєдіяльності можна сказати, що саме романіст має найширші можливості для детального, повноцінного й художньо довершеного зображення конфліктних ситуацій, конфліктів і навіть постконфліктних наслідків, як це зробив В. Винниченко в романі “Божки”.

\section{БІБЛІОГРАФІЯ}

Винниченко 1928 - Винниченко В. Божки / В. Винниченко // Твори. - Том ХІХ. K. : Рyx, 1928. - 371 c.

Волинський 1967 - Волинський П. К. Основи теорії літератури / П. К. Волинський. К. : Радянська школа, 1967. - 366 с.

Гріфцов 1926 - Грифцов Б. А. Теория романа / Б. Грифцов. - М. : Государственная Академия художественных наук, 1926. - 152 с.

Гром'як 2004 - Гром'як Р. Т. Своєрідність конфлікту в художньому світі Тараса

Шевченка / Р. Гром'як // Наукові записки. Серія: Літературознавство. - Тернопіль : ТНПУ, 2004. - Вип. ХV. - С. 3-13.

Іванов 1961 - Иванов Д. Ф. Конфликты и характеры в литературе о колхозной жизни (Проза 1953-1959 годов) : автореф. дис. ... канд. филол. наук /

Д. Ф. Иванов. - М., 1961. - 18 с. 
Карягін 1971 - Карягин А. А. Драма как эстетическая проблема / А.Карягин. - М. : Наука, 1971. - 224 c.

Катишева 2001 - Катышева Д. Вопросы теории драмы: действие, композиция, жанр / Д. Катышева. - СПб. : СПбГУП, 2001. - 205 с.

Кисельов 1962 - Киселёв Й. М. Конфликт в художественном произведении / Йосиф Михайлович Киселёв. - К. : Держлітвидав УРСР, 1962. - 76 с.

Кожинов 1964 - Кожинов В. В. Роман - эпос нового времени / В. В. Кожинов // Теория литературы / Г. Л. Абрамович и др. - Т. 2 : Основные проблемы в историческом освещении. Роды и жанры литературы. - М. : Наука, 1964. C. 97-173.

Козлов 1997 - Козлов А. В. Азбука літературознавства / Анатолій Васильович Козлов, Роман Анатолійович Козлов. - Тернопіль, 1997. - 122 с.

Корзов 1991 - Корзов Ю. И. Советская драматургия 60-80-х годов. Конфликт, действие, характер, проблемы театрально-драматургической выразительности : автореф. дис. ... д-ра филол. наук / Ю. Корзов ; Институт литературы им. Т. Г. Шевченко АН Украины. - К., 1991. - 39 с.

Косіков 1994 - Косиков Г. К. К теории романа (Роман средневековый и роман Нового времени) / Г. К. Косиков // Проблемы жанра в литературе Средневековья. Литература Средних веков. - М. : Наследие, 1994. - Вып. 1. - С. 45-87.

Лукач 1994 - Лукач Г. Теория романа. Опыт историко-философского исследования форм большой эпики / Г. Лукач // Новое литературное обозрение. - 1994. № 9. - С. 19-78.

Масєєв 1958 - Масеев И. А. Сущность и роль конфликта в искусстве / И. А. Масеев // Проблемы эстетики. - М. : АН СССР, 1958. - С. 146-154.

Мелетинський 1964 - Мелетинский Е. М. Народный епос / Е. М. Мелетинский // Теория литературы / Г. Л. Абрамович и др. - Т. 2 : Основные проблемы в историческом освещении. Роды и жанры литературы. - М. : Наука, 1964. - С. 50-97.

Муромський 1966 - Муромский В. П. Проблемы конфликта в современной советской драме (1956-1965 гг.) : автореф. дис. ... канд. филол. наук /

В. П. Муромский. - Л., 1966. - 19 с.

Нефед 1970 - Нефед В. И. Размышления о драматическом конфликте /

В. И. Нефед. - Минск : Наука и техника, 1970. - 120 с.

Норець 2008 - Норець М. В. Новаторство художнього конфлікту в російській психологічній прозі XIX сторіччя: еволюція форми (на матеріалі романів Ф. М. Достоєвського) : автореф. дис. ... канд. філол. наук : 10.01.06 / Максим Вадимович Норець ; Донецький національний університет. - Донецьк, 2008. - 12 с.

Погрібний 1981 - Погрибный А. Художественный конфликт и развитие современной советской прозы / А. Погрибный. - К. : Вища школа, 1981. - 200 с.

Сахновський-Панкеєв 1969 - Сахновский-Панкеев В. Драма. Конфликт. Композиция. Сценическая жизнь / В. Сахновский-Панкеев. - Л. : Искусство ; Ленинградский государственный институт, 1969. - 232 с.

Суркін 1965 - Суркин М. С. Конфликт в драматургии : автореф. дис. ... канд. филол. наук / М. С. Суркин ; Московский ордена Ленина и ордена трудового Красного знамени университет им. М. В. Ломоносова. - М., 1965. - 16 с.

Тамарченко 2004 - Теория литературы : учеб. пособие для студ. филол. фак. высш. учеб. заведений : в 2 т. / под ред. Н. Д. Тамарченко. - Т. 1 : Теория ху- 
дожественного дискурса. Теоретическая поэтика / Н. Д. Тамарченко, В. И. Тюпа, С. Н. Бройтман. - М. : ИЦ “Академия”, 2004. - 512 с.

Удалов 1995 - Удалов В. Теорія літератури. Цілісно-системний рівень : посібник для аспірантів, студентів університету, учителів : у 2 ч. / В. Удалов. - Ч. 1. Луцьк : Волинський державний університет ім. Лесі Українки, 1995. - 110 с. Фесенко 2008 - Фесенко Э. Я. Теория литературы: учебное пособие для вузов / Э. Я. Фесенко. - М. : Академический Проект ; Фонд “Мир”, 2008. - 780 с. Халізєв 1999 - Хализев В. Теория литературы / Владимир Хализев. - М. : Высшая школа, 1999. - $373 \mathrm{c}$.

Хороб 1999 - Хороб С. Українська драматургія: крізь виміри часу (теоретичні й історико-літературні аспекти драми) / Степан Хороб. - Івано-Франківськ : Лілея-НВ, 1999. - $200 \mathrm{c.}$

Хороб 2000 - Хороб С. Слово-образ-форма: у пошуках художності : літературознавчі статті і дослідження / Степан Хороб. - Івано-Франківськ : Плай, 2000. - 198 с. Стаття надійшла 10 жовтня 2013 p. 